\title{
Mathematical Modelling On Transportation Method Apllication For Rice Distribution Cost Optimization
}

\author{
Nuri Lutvi Azizah1 \\ ${ }^{1}$ Muhammadiyah University of Sidoarjo, Sidoarjo, Indonesia \\ Email: nurillutviazizah@umsida.ac.id
}

\begin{abstract}
RASKIN/RASTRA is a rice distribution program for the poor family with the aim of improving food security starting from the household scale. The Aim of this study is to determine whether the mathematics modelling can use in the transportation methods to provide an efficient solution of costs on the rice distribution in the region of Sidoarjo. The method used in this research is the NWC (Northwest Corner) method used to analyze the initial fiscal solution, and refined by MODI (Modified Distribution) to analyze the most optimal cost. From the calculation by transportation method, the optimum cost is lower than the company's calculation of Rp 85.186.040 while the cost of the company's calculation is Rp 87.209.690,750. Thus the use of transportation methods can save RASTRA's distribution cost of Rp 2.023.650,750.
\end{abstract}

Keywords: mathematics modelling, transportation methods, optimum cost

\section{INTRODUCTION}

RASKIN/RASTRA is a staple food subsidy in the form of rice intended for the poor as the government's efforts to increase food security and provide protection to poor families. Bulog has two activities, namely service activities and commercial business activities. But in its implementation almost $90 \%$ of the activities of the company is a service activity that is the assignment of the government [1]. "Perum BULOG Sub Divre Sidoarjo" as the implementer of RASTRA program for some areas such as Balongbendo, Buduran, Candi, Gedangan, Jabon, Krembung, Krian, Porong, Prambon, Sedati and Sidoarjo spent considerable funds for distribution activities.

To minimize the cost of this distribution it is necessary to plan for the distribution of RASTRA so that the cost of distribution issued is as optimal as possible. One method that can be used to optimize distribution costs is by transportation method. The transportation methods require a valid mathematical model before the transporatation's calculation. Mathematical model is a description of a system using mathematical concepts and language, and the process of developing a mathematical model is termed mathematical modelling.

The method of transportation is a method or means used to solve the problem of distribution from sources that provide the same product, to the place where the need optimally so that the cost of distribution issued is minimal [2]. The goal is to minimize the cost of distributing RASTRA from one location to another in the Sidoarjo area, so that the needs of each region are met according to capacity with minimal distribution cost. 


\section{METHODS}

\section{a. Transportation Method}

The Mathematical model is used to determine the mathematical equation related to the problems encountered in the problem of distribution cost optimization. The method of transportation is related to the distribution of a single product from multiple sources with limited supply, to some destinations with a particular request to obtain a minimum distribution charge. Because only one kind of product then a destination can meet the demand of one or more sources. Transportation issues have several characteristics that are [3]:

a) There are a number of sources and a number of specific goals

b) The quantity of goods distributed from each source and requested by any destination is certain

c) The quantity or quantity of goods sent from a source of destination in accordance with the request or capacity of the source

d) The cost of transportation from a source to a destination is certain

Mathematically, transportation problems can be modeled as follows:

Objective function

Minimumkan $Z=\sum_{i=1}^{m} \sum_{j=1}^{n} C_{i j} X_{i j}$

Constrain function

$\sum_{i=1}^{m} C_{i j} X_{i j}=a_{i} ; i=1,2, \ldots . . m$

$\sum_{j=1}^{n} C_{i j} X_{i j}=b_{j} ; j=1,2, \ldots ., n$

Operator definition of each variable will be described as

$\mathrm{C}_{\mathrm{ij}}=$ transportation cost per unit of goods from source $\mathrm{i}$ to destination $\mathrm{j}$

$\mathrm{X}_{\mathrm{ij}}=$ number of goods distributed from source $\mathrm{i}$ to destination $\mathrm{j}$

$\mathrm{a}_{\mathrm{i}}=$ quantity of goods offered or capacity from source $\mathrm{i}$

$b_{j}=$ quantity of goods requested or ordered by destination $j$

$\mathrm{m}=$ number of sources

$\mathrm{n}=$ number of goals

\section{b. Transportation Models}

A transport problem is said to be balanced (balance program) if the amount of supply at source $\mathrm{i}$ is equal to the amount of demand on the destination [4].Can be written:

$\sum_{i=1}^{m} a_{i}=\sum_{j=1}^{n} b_{j}$ 
The first step to solve the problem of transportation is to determine the initial feasible solution. There are three methods for determining the initial feasible solution [5] :

1. North West Corner (NWC) Method

2. The Least Cost Method

3. Vogel Approximation Method (VAM)

After obtaining the initial feasible solution then sought the optimal solution. There are two methods to determine the optimal solution [5]:

1. The stepping stone method (Stepping Stone)

2. Modified Method Of Distribution (MODI)

\section{c. Step of NWC Methods}

The method discussed in this research is Northwest Corner method for initial solution and MODI for optimal solution. The step of the NWC methods are [6]:

1. Step 1: Allocate the maximum amount available to the selected cell and adjust the associated supply and demand quantities by subtracting the allocated quantity.

2. Step 2: Exit the row or the column when the supply or demand reaches zero and cross it out, to show that it cannot make any more allocations that row or column. If a row or column simultaneously reach zero, only cross out one (the row or the column) and leave a zero supply (demand) in the row (column) that is not crosses out.

3. Step 3: if exactly one row or column is left that is not crosses out, stop. Otherwise, advance to the cell to the right if a column has just been crossed out, or to the cell below if a row was crossed out. Continue with Step 1.

\section{d. Step of MODI Methods}

While the MODI method steps are [6]:

1. Step 1: Determine the $U_{i}$ values for each row and $V_{j}$ values for each column by using the relation $C_{i j}=U_{i}+V_{j}$ for all base variables and set that the value of $U_{i}$ is zero.

2. Step 2 : Calculate the cost charges for each non based variable using $X_{i j}=C_{i j}-U_{i}-$ $V_{j}$

3. Step 3: If there is a negative $X_{i j}$ value, then the solution is not optimal. Select the $X_{i j}$ variable with the largest negative value as the entering variable.

4. Step 4 : Allocated goods entering variable $X_{i j}$ according stepping stone or NWC process

5. Step 5: Repeat Step 1 through Step 4 until all $X_{i j}$ values are zero or positive.

\section{e. Data Collection Technique}

The main problem faced in this research is not optimal the fund spent for rice distribution cost in "Perum Bulog Sub Divre Sidoarjo", so after mathematical modelling used in this research, the transportation method will be applied to get the most optimal cost solution. Here is a Data Collection Technique used are:

a. Study of Literature

b. Secondary Data Retrieval

This study uses secondary data obtained from "Perum Bulog Sub Divre Sidoarjo", and can be done using assumptions to be used for similar problems.

c. Observation

This activity is done to synchronize the secondary data obtained by doing direct observation of the spaciousness to ensure the data obtained is valid.

d. System Planning Using Mathematics model

e. Implementation of transportation methods 


\section{RESULTS AND DISCUSSION}

\section{a. Rice Distribution Data for RASKIN/RASTRA}

The RASTRA distribution data consist of the amount of RASTRA rice distributed per month in kilograms (kg), for each area sub-div described in several districts/cities. In each sub div of the districts, there are number of distribution points (TD), and at the village level with the number of Target Household (RTS) receiving RASTRA [7]. In this research, RASTRA distribution in point emphasizes on the distribution from warehouse to the subdistrict level to find out how much the cost from the warehouse to the distribution place in the area to the sub district where rice distribution area. For the value to be measured for completion in this research is the amount of distribution or distribution of RASTRA rice per month in kilogram $(\mathrm{kg})$ then be converted in tons/year as needed. The amount of RASTRA rice distribution per month in North Surabaya region can be seen in Table 1.

Table 1. RASTRA Rice Distribution per Month

\begin{tabular}{clcc}
\hline \multirow{2}{*}{ NO } & SUBDIVRE & \multicolumn{2}{c}{ Distribution per Month } \\
\cline { 2 - 4 } & KAB/KOTA & RTS-PM & Kg \\
\hline I & SURABAYA UTARA & 221.845 & 3.327 .675 \\
\hline $\mathbf{1 .}$ & Kota Surabaya & 65.991 & 989.865 \\
\hline 2. & Kab. Sidoarjo & 78.103 & 1.171 .545 \\
\hline 3. & Kab. Gresik & 77.751 & 1.166 .265 \\
\hline
\end{tabular}

Sidoarjo District consist of 18 Sub-District formed five clusters for distribution of rice RASTRA, details for five clusters with members called Distribution Point (TD) that include within each cluster can be seen in Table 2 .

Table 2. Capacity Data for Each Region in RASTRA Distribution

\begin{tabular}{|c|c|c|c|}
\hline No & Warehouse & Location & Capacity (per kg) \\
\hline 1 & Warehouse 1 & Gedangan & 265045 \\
\hline 2 & Warehouse 2 & Gedangan & 257500 \\
\hline 3 & Warehouse 3 & Gedangan & 230000 \\
\hline 4 & Warehouse 4 & Porong & 201000 \\
\hline 5 & Warehouse 5 & Porong & 218000 \\
\hline & Total & & 1171545 \\
\hline
\end{tabular}

\section{b. Description of Distance Data}

Distance data is retrieved through Google Maps data source to know the distance of warehouse with the sub-district or rice distribution/distribution area for RASTRA [7]. The verification of the distance data that has been collected can be seen in Table 3, it contains the relative distance data collection from the warehouse to the sub-districts where the distribution to the RTS. 
Table 3. Relative Distance Data from Warehouse to the Sub-District

\begin{tabular}{clc}
\hline No. & Location & $\begin{array}{c}\text { Warehouse/Sub District } \\
\text { Distance(km) }\end{array}$ \\
\hline $\mathbf{1}$ & Balongbendo & 28,02 \\
\hline $\mathbf{2}$ & Buduran & 0,5 \\
\hline $\mathbf{3}$ & Candi & 9 \\
\hline $\mathbf{4}$ & Gedangan & 3,5 \\
\hline $\mathbf{5}$ & Jabon & 19,3 \\
\hline $\mathbf{6}$ & Krembung & 24,9 \\
\hline $\mathbf{7}$ & Krian & 18,3 \\
\hline $\mathbf{8}$ & Porong & 17,6 \\
\hline $\mathbf{9}$ & Prambon & 27,7 \\
\hline $\mathbf{1 0}$ & Sedati & 7,8 \\
\hline $\mathbf{1 1}$ & Sidoarjo & 6,1 \\
\hline $\mathbf{1 2}$ & Sukodono & 7,5 \\
\hline $\mathbf{1 3}$ & Taman & 12,2 \\
\hline $\mathbf{1 4}$ & Tanggulangin & 12,5 \\
\hline $\mathbf{1 5}$ & Tarik & 32,8 \\
\hline $\mathbf{1 6}$ & Tulangan & 18,8 \\
\hline $\mathbf{1 7}$ & Waru & 10,8 \\
\hline $\mathbf{1 8}$ & Wonoayu & 15,1 \\
\hline
\end{tabular}

The following data on the amount of RASTRA rice required depend on the Distance Data by Google Maps Application and can be seen on Table 4.

Table 4. RASKIN Rice Required Amount in each Region in kg of rice

\begin{tabular}{|c|c|c|c|c|}
\hline NO & WAREHOUSE & $\begin{array}{c}\text { SUB } \\
\text { DISTRICT }\end{array}$ & $\begin{array}{l}\text { RICE CAPACITY } \\
\text { (KG)/DEMAND }\end{array}$ & TOTAL \\
\hline \multirow[t]{4}{*}{1} & \multirow[t]{4}{*}{ Warehouse 1} & Buduran & 69000 & \multirow[t]{4}{*}{280425} \\
\hline & & Sedati & 71035 & \\
\hline & & Gedangan & 71985 & \\
\hline & & Sidoarjo & 68405 & \\
\hline \multirow[t]{4}{*}{2} & \multirow[t]{4}{*}{ Warehouse 2} & Candi & 67600 & \multirow[t]{4}{*}{246160} \\
\hline & & Tanggulangin & 53500 & \\
\hline & & Wonoayu & 60035 & \\
\hline & & Tulangan & 65025 & \\
\hline \multirow[t]{4}{*}{3} & \multirow[t]{4}{*}{ Warehouse 3} & Sukodono & 50025 & \multirow[t]{4}{*}{234635} \\
\hline & & Taman & 52000 & \\
\hline & & Krian & 75545 & \\
\hline & & Waru & 57065 & \\
\hline \multirow[t]{3}{*}{4} & \multirow[t]{3}{*}{ Warehouse 4} & Balongbendo & 68050 & \multirow[t]{3}{*}{198080} \\
\hline & & Tarik & 61030 & \\
\hline & & Prambon & 69000 & \\
\hline \multirow[t]{2}{*}{5} & \multirow[t]{2}{*}{ Warehouse 5} & Krembung & 67000 & \multirow[t]{2}{*}{212245} \\
\hline & & Porong & 77245 & \\
\hline
\end{tabular}


TOTAL

Jabon

68000

1171545

1171545

\section{Mathematical Modelling}

Preparation of data is done by translating the problems and descriptions into the form of mathematical models. Formation of the mathematical model of the data obtained need to pay attention to things that affect the calculation process, such as:

1. Decision Variable

2. Objective Function

3. Constrains

The steps to be taken in the transport model are the determination of decision variables, objective functions, and constraints.

1. Decision Variable

Here are the variables for delivery allocation to each warehouse

Alocation Distribusion from GBB Banjar Kemantren 1 (Warehouse 1)

a. Allocation from warehouse 1 to several point distribution

$\boldsymbol{X}_{\mathbf{1 1}}=$ Allocation from Warehouse 1 to Point Distribution 1,

$\boldsymbol{X}_{\mathbf{1 2}}=$ Allocation from Warehouse 1 to Point Distribution 2,

$\boldsymbol{X}_{13}=$ Allocation from Warehouse 1 to Point Distribution 3,

$\boldsymbol{X}_{\mathbf{1 4}}=$ Allocation from Warehouse 1 to Point Distribution 4

$\boldsymbol{X}_{\mathbf{1 5}}=$ Allocation from Warehouse 1 to Point Distribution 5

b. Allocation from warehouse 2 to several point distribution

$\boldsymbol{X}_{\mathbf{2 1}}=$ Allocation from Warehouse 2 to Point Distribution 1

$\boldsymbol{X}_{\mathbf{2 2}}=$ Allocation from Warehouse 2 to Point Distribution 2

$\boldsymbol{X}_{\mathbf{2 3}}=$ Allocation from Warehouse 2 to Point Distribution 3

$\boldsymbol{X}_{\mathbf{2 4}}=$ Allocation from Warehouse 2 to Point Distribution 4

$\boldsymbol{X}_{\mathbf{2 5}}=$ Allocation from Warehouse 2 to Point Distribution 5

c. Allocation from warehouse 3 to several point distribution

$\boldsymbol{X}_{\mathbf{3 1}}=$ Allocation from Warehouse 3 to Point Distribution 1

$\boldsymbol{X}_{32}=$ Allocation from Warehouse 3 to Point Distribution 2

$\boldsymbol{X}_{\mathbf{3 3}}=$ Allocation from Warehouse 3 to Point Distribution 3

$\boldsymbol{X}_{\mathbf{3 4}}=$ Allocation from Warehouse 3 to Point Distribution 4

$\boldsymbol{X}_{35}=$ Allocation from Warehouse 3 to Point Distribution 5

d. Allocation from warehouse 4 to several point distribution

$\boldsymbol{X}_{\mathbf{4 1}}=$ Allocation from Warehouse 4 to Point Distribution 1

$\boldsymbol{X}_{\mathbf{4 2}}=$ Allocation from Warehouse 4 to Point Distribution 2

$\boldsymbol{X}_{\mathbf{4 3}}=$ Allocation from Warehouse 4 to Point Distribution 3

$\boldsymbol{X}_{\mathbf{4 4}}=$ Allocation from Warehouse 4 to Point Distribution 4

$\boldsymbol{X}_{\mathbf{4 5}}=$ Allocation from Warehouse 4 to Point Distribution 5

e. Allocation from warehouse 5 to several point distribution

$\boldsymbol{X}_{\mathbf{5 1}}=$ Allocation from Warehouse 5 to Point Distribution 1

$\boldsymbol{X}_{\mathbf{5 2}}=$ Allocation from Warehouse 5 to Point Distribution 2

$\boldsymbol{X}_{53}=$ Allocation from Warehouse 5 to Point Distribution 3

$\boldsymbol{X}_{\mathbf{5 4}}=$ Allocation from Warehouse 5 to Point Distribution 4

$\boldsymbol{X}_{\mathbf{5 5}}=$ Allocation from Warehouse 5 to Point Distribution 5 
2. Objective Function

Optimization The function $Z$

$Z=\sum_{i=1}^{m} \sum_{j=1}^{n} C_{i j} X_{i j}$

So that the formulation based on the data became a linear programming formulation and can be formulated by matrix calculation.

$Z=71,25 X_{11}+75 X_{12}+80 X_{13}+110,25 X_{14}+102,675 X_{15}+73 X_{21}+$

$77,5 X_{22}+76,15 X_{23}+117,15 X_{24}+81,765 X_{25}+70,5 X_{31}+78,25 X_{32}+$

$82,75 X_{33}+105,25 X_{34}+88,85 X_{35}+80 X_{41}+85,75 X_{42}+76,75 X_{43}+$

$71,05 X_{44}+71,75 X_{45}+101,75 X_{51}+90,25 X_{52}+80,75 X_{53}+71,85 X_{54}+$

$70,25 X_{55}$.

3. Constrains

Constrains in this research can be divided into two categories. First constrain is for demanding problem and the second is for bargaining problem. Here is the same about demanding constrain and bargaining constrains.

$X_{11}+X_{21}+X_{31}+X_{41}+X_{51}=280425$

$X_{12}+X_{22}+X_{32}+X_{42}+X_{52}=246160$

$X_{13}+X_{23}+X_{33}+X_{43}+X_{53}=234635$

$X_{14}+X_{24}+X_{34}+X_{44}+X_{54}=198080$

$X_{15}+X_{25}+X_{35}+X_{45}+X_{55}=21224$

\section{Program Formulation}

The compilation from the formulation and equations is using the computational program as a QM for Windows script. The problem solving for RASTRA rice distribution cost optimization can be seen on the Table 5 by Northwest Corner Methods to determine initial fiscal point.

\begin{tabular}{c|ccccr}
\multicolumn{6}{c}{ Table 5. Solution Report for Northwest Corner (NWC) Methods } \\
SOLUTION & $\begin{array}{c}\text { DISTRICT } \\
\text { VALUE }\end{array}$ & \multicolumn{1}{c}{ DISTRICT } & DISTRICT & DISTRICT & \multicolumn{1}{c}{ DISTRICT } \\
\$87440020 & & 2 & 3 & 4 & 5 \\
WAREHOUSE 1 & 265045 & $(-0.75)$ & $(0.25)$ & $(35.7)$ & $(-29.725)$ \\
WAREHOUSE 2 & 15380 & 242120 & $(-5.85)$ & $(40.85)$ & $(-7.065)$ \\
WAREHOUSE 3 & $(-3.25)$ & 4040 & 225969 & $(28.2)$ & $(13.4)$ \\
WAREHOUSE 4 & $(12.25)$ & $(13.5)$ & 8675 & 192325 & $(2.3)$ \\
WAREHOUSE 5 & $(33.2)$ & $(17.2)$ & $(3.2)$ & 5755 & 212245
\end{tabular}

After the initial value or point obtained from NWC method, then the calculation and the program compilation is continued with MODI method to get the optimal Solution, it can be seen on the Table 6 .

Table 6. Solution Report for MODI by using initials NWC Method

\begin{tabular}{|c|c|c|c|c|c|}
\hline $\begin{array}{l}\text { SOLUTION } \\
\text { VALUE }\end{array}$ & $\begin{array}{c}\text { DISTRICT } \\
1\end{array}$ & $\begin{array}{l}\text { DISTRICT } \\
\quad 2\end{array}$ & $\begin{array}{c}\text { DISTRICT } \\
3\end{array}$ & $\begin{array}{c}\text { DISTRICT } \\
4\end{array}$ & $\begin{array}{c}\text { DISTRICT } \\
5\end{array}$ \\
\hline$\$ 85186040$ & & & & & \\
\hline WAREHOUSE 1 & 18885 & 246160 & (5.6) & (41.55) & (35.575) \\
\hline WAREHOUSE 2 & 31540 & $(0.75)$ & 225960 & $(46.7)$ & (12.915) \\
\hline WAREHOUSE 3 & 230000 & (4) & (9.1) & (37.3) & $(22.5)$ \\
\hline
\end{tabular}




\begin{tabular}{r|rrrrr} 
WAREHOUSE 4 & $(6.4)$ & $(8.4)$ & 8675 & 192325 & $(2.3)$ \\
WAREHOUSE 5 & $(27.35)$ & $(12.1)$ & $(3.2)$ & 5755 & 212245
\end{tabular}

The solution report from QM for windows compilation obtained that the NWC method has the solution value about $\$ 87440020$. The MODI method by using the initial fiscal point NWC method has the solution value about $\$ 85186040$.

\section{CONCLUSION}

Mathematical modelling on the transportation methods will produce a mathematical equations useful for optimization problem solving if the model used is a valid model. Based on the result of QM for Windows compilations is known that transportation with the initial NWC method to determine the initial value has the solution value about Rp 87.440.020. The MODI method is used to determine the optimal solution by using initial fiscal point in NWC method has the solution value about Rp 85.186.040. The MODI method obtain the optimal solution and it can save cost about Rp 2.253.980 from the NWC method. The secondary data that given from the calculation "Perum Bulog Sub-Divre Sidoarjo" has minimal cost about Rp 87.209.690,750. So that, with the MODI method can save RASTRA rice distribution cost about $\mathrm{Rp} 2.023 .650,750$.

\section{REFERENCES}

[1] H, A. Taha. (1997). Operation Research An Introduction. University of Arkansas, Fayetteville: Prentice Hall, vol. 6, pp. 202-230.

[2] Clark, S. D. (2002). Handbook of Transportation Science. Journal of the Operational Research Society (Vol. 53, pp. 470-471). https://doi.org/10.1017/CB09781107415324.004

[3] T, D, A, Dimyati. Operation Research. (2003). Handbook of Operation Research. Bandung : Sinar Baru Algesindo, vol. 3, pp. 304-325.

[4] Shay, E., Combs, T. S., Findley, D., Kolosna, C., Madeley, M., \& Salvesen, D. (2016). Identifying transportation disadvantage: Mixed-methods analysis combining GIS mapping with qualitative data. Transport Policy, 48, 129-138. https://doi.org/10.1016/j.tranpol.2016.03.002

[5] Simbolon, L. D. Situmorang., N. Napitupulu. Aplikasi Metode Transportasi dalam Optimasi Biaya Distribusi Beras Miskin (Raskin) pada PERUM Bulog Sub Divre Medan. Jurnal Saintia Matematika, vol.02, 2337-9197.

[6] Siswanto. (2007).Operation Research. Handbook of Operation Research. Jakarta : Penerbit Erlangga, Vol. 01, pp. 175-215.

[7] Riskiet, Al. (2007).Implementasi dan Penyaluran RASKIN Perum Bulog Divre di Indonesia. Jurnal Aplikasi Matematika, vol. 01, pp 01-07. 